\title{
IMPLEMENTATION OF EDUCATIONAL NATIONAL STANDARD POLICY ON THE OPERATION OF BASIC EDUCATION (Case Study in Wajo District, South Sulawesi)
}

\author{
Sitti Aminah, Imran Ismail \\ STKIP Puangrimaggalatung Sengkang \\ imranismail352@gmail.com
}

Article History

accepted 09/07/2018

approved 01/08/2018

published 17/09/2018

\section{Keywords}

National Education Standards, The Primary

School Policy

\begin{abstract}
The background study of this research is to develop national education standards of the basic education. In this research study, the researcher tries to see and analyze the prevailing condition schools in the field of education. The goals of this research knowledge of the implementation of the National Education Standards policy and the determinant factors can support the implementation of National Education Standards policy on the implementation of National Standard School in Wajo Regency. The design of this research was descriptive qualitative research. The data for this research was collected through observation, interview, and documentation. The resulting analysis can be concluded as follows: First, the stages of implementation of the National Standard Primary School policy have not been implemented optimally because of overlapping. Second, the determinant factors that influence the implementation of the National Standard Primary School policy include resource support is still very limited, and third, less motivated elementary schools to get involved in the implementation of the National Standard Primary School policy, especially elementary schools in the standard category. In suggestion, good cooperation is needed with all parties and stakeholders in the implementation of the National Standard Primary School program through efforts to obtain common views and responsibilities towards Primary School development.
\end{abstract}

Social, Humanities, and Education Studies (SHEs): Conference Series https://jurnal.uns.ac.id/shes
p-ISSN 2620-9284

e-ISSN 2620-9292 


\section{PENDAHULUAN}

Sesuai dengan amanat Pembukaan Undang-Undang Dasar Negara Republik Indonesia tahun 1945 alinea keempat menyatakan bahwa Tujuan Nasional adalah melindungi segenap bangsa Indonesia dan seluruh tumpah darah Indonesia dan untuk memajukan kesejahteraan umum, mencerdaskan kehidupan bangsa, dan ikut melaksanakan ketertiban dunia yang berdasarkan kemerdekaan perdamaian abadi dan keadilan sosial. Untuk menjabarkan Tujuan Nasional, khususnya dalam rangka mencerdaskan kehidupan bangsa, maka telah disusun Undang-Undang Nomor 20 tahun 2003 tentang Sistem Pendidikan Nasional sebagai pedoman pelaksanaan pendidikan, termasuk Pendidikan Dasar.

Amanah ini menjadi kewajiban pemerintah dalam melaksanakan setiap kebijakan pendidikan yang diambil untuk mencapai tujuan pendidikan nasional tersebut, sehingga arah kebijakan pendidikan menjadi bagian dari upaya melaksanakan amanat yang terkandung dalam Undang- Undang Dasar Negara Republik Indonesia tahun 1945 Pasal 31 Ayat 3 yang berbunyi : "Pemerintah mengusahakan dan menyelenggarakan satu sistem pendidikan nasional, yang meningkatkan keimanan dan ketakwaan serta akhlak mulia dalam rangka mencerdaskan kehidupan bangsa, yang diatur dengan undang-undang".

Pendidikan adalah suatu proses belajar-mengajar yang dilakukan dengan sengaja, sadar dan berencana yang membiasakan para warga masyarakat sedini mungkin untuk menggali, mengenal, memahami, menyadari, menguasai, menghayati, mengamalkan nilai-nilai yang disepakati bersama, dikehendaki berguna bagi kehidupan serta perkembangan pribadi masyarakat, bangsa dan negara.

Salah satu pokok masalah yang dihadapi bangsa Indonesia, terutama dalam era globalisasi saat ini adalah kondisi dan sumber daya manusia (SDM) yang relatif rendah yang ditunjukkan oleh data statistik bahwa $60 \%$ guru SD, $40 \%$ guru SLTP, $43 \%$ guru SMA, 34\% guru SMK dianggap belum layak untuk mengajar di jenjang masingmasing. Selain itu 17,2\% guru atau setara dengan 69.477 guru mengajar bukan bidang studinya (Mulyasa, 2007).

Untuk melaksanakan Undang-Undang Nomor 20 tahun 2003 terlebih dahulu menentukan standar yang harus menjadi acuan pelaksanaan kegiatan pendidikan, maka untuk itu pemerintah mengeluarkan Peraturan Pemerintah Nomor 19 Tahun 2005 tentang Standar Nasional Pendidikan (SNP) pasal 1 bahwa SNP adalah kriteria minimal tentang sistem pendidikan di seluruh wilayah hukum Negara Kesatuan Republik Indonesia, yang kemudian dibentuk pula Badan Standar Nasional Pendidikan (BNSP) sebagai badan yang menentukan 8 (delapan) Standar Pendidikan dan kriteria pencapaian penyelenggaraan pendidikan.

Adapun standar-standar yang menjadi dasar bagi penyelenggaraan pendidikan sebagaimana yang diatur dalam Pasal 2 Peraturan Pemerintah Nomor 19 Tahun 2005 yaitu: 1) Standar Isi, 2) Standar Proses, 3) Standar Kompetensi Lulusan, 4) Standar Pendidik dan Tenaga Kependidikan, 5) Standar Sarana dan Prasarana Pendidikan, 6)Standar Pengelolaan, 7)Standar Pembiayaan dan 8)Standar Penilaian Pendidikan

Upaya peningkatan mutu pendidikan harus dilakukan secara terpadu antara penyelenggara dan pembina pendidikan di semua tingkatan dengan satuan/program pendidikan dalam kerangka Sistem Penjaminan Mutu Pendidikan, sebagaimana diatur dalam Peraturan Menteri Pendidikan Nasional (Permendiknas) Nomor 63 Tahun 2009 tentang Sistem Penjaminan Mutu Pendidikan.

Untuk menunjang keberhasilan Sistim Penjaminan Mutu Pendidikan (SPMP) di tingkat kabupaten/kota, dinas pendidikan sudah mempunyai jalur perolehan data dan informasi tentang pelaksanaan pendidikan di daerahnya. Untuk mengoptimalkan upaya tersebut, saat ini sedang dikembangkan dua kegiatan baru yang akan membantu Dinas Pendidikan (Diknas) maupun Kementerian Agama (Kemenag) untuk 
memperoleh data dan informasi pelaksanaan pendidikan di daerah masing-masing dengan mengacu pada Standar Pelayanan Minimal (SPM) dan Standar Nasional Pendidikan (SNP). Kedua kegiatan tersebut yakni Evaluasi Diri Sekolah (EDS) dan Monitoring Sekolah oleh Pemerintah Daerah (MSPD).

Implementasi kebijakan Standar Nasional Pendidikan pada Sekolah Dasar di kabupaten Wajo khususnya, dalam menerapkan 8 standar nasional pendidikan belum dilakukan secara menyeluruh sesuai standar nasional. Data menunjukkan bahwa dari jumlah 306 Sekolah Dasar Negeri, hanya 11 Sekolah Dasar yang tergolong kategori Sekolah Dasar Standar Nasional (Disdik Wajo, 2012). Hal ini menunjukkan terdapat fenomena empiris tentang kebijakan standar nasional pendidikan yang diamanatkan oleh Peraturan Pemerintah No. 19 tahun 2005 belum optimal dilaksanakan, bahkan terdapat kecenderungan belum sepenuhnya dilaksanakan sesuai Standar Nasional Pendidikan.

Selanjutnya terdapat beberapa hal penting yang mendorong peneliti untuk melakukan penelitian tentang "Implementasi Kebijakan Standar Nasional Pendidikan Pada Penyelenggaraan Pendidikan Dasar di Kabupaten Wajo" yaitu (1) pada tatanan akademik di Indonesia khususnya Sulawesi Selatan, penelitian dalam konteks standar nasional pendidikan dikaitkan dengan penyelenggaraan sekolah dasar berstandar nasional relatif baru, (2) Tuntutan sekolah yang berkualitas berdasarkan delapan standar nasional pendidikan, (3) perlunya sistem penjaminan mutu pendidikan yang merata di setiap wilayah kabupaten / kecamatan, (4) Penelitian ini diharapkan menemukan model strategi implementasi kebijakan pendidikan atau solusi baru mengenai standar nasional pendidikan dalam penyelenggaraan sekolah dasar yang berstandar nasional. Hal - hal yang dikemukakan tersebut di atas mengacu pada ketentuan Peraturan Pemerintah No. 19 Tahun 2005 tentang standar nasional pendidikan dan serta Peraturan bersama antara Direktur Jenderal Pendidikan Dasar \& Menengah dan Direktur Jenderal Pendidikan Anak Usia Dini \& Pendidikan Masyarakat No: 07/D/BP/2017 \& No : 02/MPK.C/PM/2017 Tentang Petunjuk pelaksanaan program Indonesia pintar tahun 2017. Berangkat dari pemikiran di atas, perlu dilakukan penelitian tentang "Kebijakan Standar Nasional Pendidikan pada Penyelenggaraan Pendidikan Dasar di Kabupaten Wajo."

Berdasarkan deskripsi fenomena dan problem implementasi kebijakan Standar nasional Pendidikan pada latar belakang, maka dapat dirumuskan beberapa permasalahan yang menjadi pusat kajian dalam penelitian ini yaitu:

1. Bagaimana tahapan implementasi kebijakan Standar Nasional Pendidikan pada penyelenggaraan Sekolah Dasar Standar Nasional di Kabupaten Wajo?

2. Faktor-faktor determinan apa yang dapat mendukung implementasi kebijakan Standar Nasional Pendidikan pada penyelenggaraan Sekolah Dasar Standar Nasional di Kabupaten Wajo?

3. Bagaimana wujud implementasi kebijakan Standar Nasional Pendidikan pada penyelenggaraan Sekolah Dasar Standar Nasional di Kabupaten Wajo?

\section{METODE}

Penelitian ini menggunakan pendekatan kualitatif yang bertujuan untuk mengkaji permasalahan dan memperoleh makna yang lebih mendalam sesuai dengan latar penelitian. Penggunaan pendekatan kualitatif dalam penelitian ini didasarkan pula atas pertimbangan agar: (1) lebih mudah menyesuiakan jika berhadapan dengan kenyataan ganda; (2) dapat menyajikan langsung hakikat hubungan antara peneliti dengan responden; (3) lebih peka dan lebih dapat menyesuaikan diri dengan banyak penajaman pengaruh bersama dan terhadap pola-pola nilai yang dihadapi. Teknik pengumpulan data penelitian ini menggunakan tiga teknik utama, yaitu observasi, wawancara, dan studi dokumentasi.Observasi penulis lakukan secara berkelanjutan 
agar diperoleh informasi dari tangan pertama mengenai masalah yang diteliti dan kondisi implementasi kebijakan standar nasional pendidikan pada penyelenggaraan Sekolah Dasar di Kabupaten Wajo. Pelaksanaan wawancara pada prinsipnya dimaksudkan untuk mendapatkan data yang cukup sehubungan dengan pokok masalah penelitian yang telah diidentifikasi. Kegiatan wawancara ini penulis lakukan secara terus menerus dengan responden dalam berbagai situasi, meskipun kadangkala dilakukan pula dalam situasi yang khsusus. Selain observasi dan wawancara, penulis menggunakan pula teknik pengumpulan data melalui studi dokumentasi. Data yang diperoleh dari studi dokumentasi, penulis manfaatkan sebagai bahan triangulasi untuk pengecekan kesesuaian data. Analisis data yang penulis lakukan, mengikuti proses sebagaimana yang dianjurkan oleh Moleong (2010:37), yaitu dimulai dengan menelaah seluruh data yang tersedia dari berbagai sumber, yaitu dari wawancara dan pengamatan yang sudah dituliskan dalam catatan lapangan, dokumen pribadi, dokumen resmi, gambar, foto, dan sebagainya. Adapun prosedur analisis data yang penulis tempuh dalam penelitian ini terdiri atas empat langkah berikut ini.

\section{HASIL PENELITIAN DAN PEMBAHASAN Dalam Tahapan Implementasi Kebijakan Standar Nasional Pendidikan Sekolah Dasar Standar Nasional}

Secara formal, usulan penyelenggaraan sekolah dasar standar nasional di Kabupaten Wajo dilaksanakan berdasarkan ketentuan dan persyaratan yang diatur dalam Undang-Undang Nomor 20 Tahun 2003 dan dijabarkan dalam Peraturan Pemerintah No.19 Tahun 2005 mengupayakan standar nasional.Dalam implementasi kebijakan standar nasional pendidikan, penyelenggaraan Sekolah Dasar Standar Nasional di Kabupaten Wajo, para pelaksana kebijakan menghadapi berbagai tantangan dan hambatan. Namun demikian, tantangan dan hambatan tersebut dapat diatasi dengan baik, sehingga Kabupaten Wajo dinilai sebagai salah satu daerah yang berhasil menerapkan Sekolah Dasar Standar Nasional di Sulawesi Selatan.

Proposisi diatas didukung oleh bukti-bukti fisik maupun non fisik yang ditemukan di lokasi penelitian. Hasil observasi, wawancara dengan para informan, serta pengkajian berbagai dokumen yang terkait dengan implementasi kebijakan SNP menunjukkan bahwa pemerintah daerah berhasil (1) melaksanakan tahapan implementasi kebijakan Standar Nasional Pendidikan, (2) mengelola dan memanfaatkan faktor-faktor determinan dalam implementasi kebijakan, (3) mewujudkan implementasi kebijakan Standar Nasional Pendidikan - Sekolah Dasar Standar Nasional sesuai dengan tujuan, tuntutan dan harapan masyarakat.

Tahapan Implementasi Kebijakan Standar Nasional Pendidikan

Secara teoritis, implementasi kebijakan Standar Nasional Pendidikan dalam penyelenggaraan Sekolah Dasar Standar Nasional di Kabupaten Wajo berdasarkan konten dan konteks implementasi kebijakan sebagaimana yang dikemukakan oleh Merilee S Grindle, Edward III, Mazmanian \& Sabiraties, Van Moller \& Cool Van Hora Brian Hogwood dan Richard Elmore.

Orientasi Kepentingan Masyarakat Pendidikan

Pemerintah Kabupaten Wajo memberikan buku tulis dan alat tulis bagi siswa kurang mampu. Disamping itu siswa di sekolah yang sama mendapatkan buku mata pelajaran dan buku lembar kerja siswa sehingga mereka tidak lagi memikirkan untuk membeli buku tulis dan buku mata pelajaran bahkan LKS setiap mata pelajaran.

Tahapan Implementasi Kebijakan Standar Nasional Pendidikan - Sekolah Dasar Standar Nasional

Kebijakan implementasi kebijakan Sekolah Dasar Standar Nasional setidaknya terdapat empat tahapan yang harus dilaksanakan sehingga sasaran pelaksanaannya 
dapat dicapai secara optimal. Tahapan-tahapan sebagaimana disebutkan tersebut adalah: (1) sosialisasi Sekolah Dasar Standar Nasional (2) pendataan anak usia Sekolah Dasar Standar Nasional (3) penyediaan dana, sarana dan fasilitas penunjang, dan (4) monitoring dan evaluasi Sekolah Dasar Standar Nasional. Keempat tahapan ini dilaksanakan secara berkala dan berkesinambungan sesuai dengan realisasi dana yang dianggarkan pemerintah pusat maupun daerah.

\section{Faktor-Faktor Determinan Pelaksanaan Implementasi Kebijakan Standar Nasional Pendidikan - Sekolah Dasar Standar Nasional}

1. Faktor Internal Implementasi Kebijakan

a. Sumberdaya yang digunakan

Dalam implementasi kebijakan sumberdaya tergolong pada kategori faktor internal dan sangat menentukan. Hal ini sejalan dengan teori yang disampaikan oleh Merilee S Grindle, Edwards III, Hogwood dan Gunn, Ripley bahwa, faktor sumberdaya merupakan salah satu faktor penentu dalam keberhasilan implementasi kebijakan publik.

b. Faktor Komunikasi dan Koordinasi

Faktor komunikasi dan koordinasi sangat menentukan dalam suatu kebijakan, Secara teoritis, hal ini relevan dengan pendapat Edwards III, Grindle, Mazmanian dan Sabatier yang mengatakan bahwa komunikasi dan koordinasi merupakan salah satu faktor yang sangat menentukan keberhasilan implementasi kebijakan.

c. Posisi Pengambilan Keputusan

Peneliti menyimpulkan bahwa suatu kebijakan dapat diimplementasikan dengan baik apabila para implementornya betul-betul memiliki komitmen untuk menjalankan kebijakan tersebut.

d. Dukungan Struktur Birokrasi Dalam Pelaksanaan Program

Implementasi kebijakan Sekolah Dasar Standar Nasional di Kabupaten Wajo memperkuat adanya keterlibatan stakeholder baik pemerintah maupun masyarakat (orang tua dan guru) dan adanya pembagian tugas bagi aparat pelaksana mendukung proses implementasi kebijakan Sekolah Dasar Standar Nasional dan berjalan dengan baik.

Hal ini relevan dengan teori yang dikemukakan oleh Edwards III yang mengatakan bahwa dalam implementasi kebijakan, dukungan dari pemerintah berupa pembagian tugas dan penetapan Standard Operational Procedure (SOP) sangat menentukan keberhasilan dalam implementasi kebijakan.

2. Faktor Eksternal Implementasi Kebijakan

a. Pengaruh Kondisi Ekonomi Masyarakat dan Kekuasaan

Faktor kondisi ekonomi masyarakat harus diperhatikan karena turut menentukan keberhasilan program pendidikan. Realitas empirik yang ditemukan berdasarkan pengamatan bahwa ada sebagian masyarakat yang mengalami kesulitan dalam menyekolahkan anaknya karena faktor ekonomi.

b. Karakteristik Lembaga

Kondisi lingkungan tempat tinggal anak sekolah harus diperhatikan sebagai salah faktor yang menentukan keberhasilan implementasi kebijakan Sekolah Dasar Standar Nasional. Oleh karena itu, lingkungan harus diperhatikan terutama bagi sekolah-sekolah yang berada di pusat keramaian (pusat perkotaan). Memperhatikan faktor lingkungan tentunya sasaran akhir dari kebijakan Sekolah Dasar Standar Nasional di Kabupaten Wajo dapat tercapai dengan sebaik mungkin.

c. Pengaruh Budaya Masyarakat dan Karakteristik Lembaga

Hasil pengamatan menunjukkan bahwa, ada ketimpangan budaya yang terjadi di tengah-tengah masyarakat, dimana budaya yang seharusnya sebagai tradisi yang 
ada di dalam kehidupan masyarakat, bergeser pada budaya atau tradisi masyarakat yang biasanya menganggap anak sebagai tenaga kerja yang dapat difungsikan untuk meringankan pekerjaan orang tuanya. Hal ini sangat bertolak belakang dengan budaya lokal yang memiliki corak dan budaya untuk menjunjung tinggi nilai-nilai luhur masyarakat berupa gotong royong dalam berbagai aspek kehidupan.

\section{Analisis Konten dan Konteks Implementasi Kebijakan Pendidikan pada SD-SN}

1. Analisis Implementasi Kebijakan Standar Nasional

Implementasi kebijakan pendidikan merupakan suatu rangkaian penugasan birokrasi pendidikan yang berlangsung secara berjenjang dan berkaitan. Rangkaian poenugasan tersebut dapat berlaku secara efektif bila didasarkan pada pola komunikasi yang efektif. Pola komunikasi yang efektif untuk mendukung tercaapainya tujuan dan sasaran implementasi kebijakan standar nasional pendidikan sekurang-kurangnya mencakup indikator-indikator kejelasan informasi kebijakan standar nasional pendidikan; keakuratan informasi kebijakan standar nasional pendidikan; dan konsistensi informasi kebijakan standar nasional pendidikan.

2. Analisis Konten dan Konteks Implementasi Kebijakan Pendidikan pada SD-SN

Kualitas pelayanan pendidikan juga memerlukan berbagai fasilitas yang bersumber dari faktor tangibles (bukti fisik), untuk mengukur ketersedian sarana fisik/bangunan, infrastruktur, faktor responsiveness (daya tanggap), untuk mengukur bagaimana kesiapan petugas dalam membantu dan memberikan pelayanan kepada pelanggan dengan cepat,faktor assurance (jaminan), untuk mengukur kemampuan dan kesopanan karyawan serta sifat dapat dipercaya yang dimiliki oleh karyawan; faktor empathy (empati), untuk mengukur pemahaman karyawan terhadap kebutuhan konsumen serta perhatian yang diberikan oleh karyawan; dan faktor reability (keandalan), untuk mengukur kemampuan perusahaan dalam memberikan jasa yang tepat dan dapat diandalkan.

Berdasarkan operasionalisasi variabel Kualitas Pelayanan Pendidikan pada Sekolah Dasar pada dimensi tangible yang meliputi indikator-indikator yang mempengaruhi kualitas pelayanan pendidikan Sekolah Dasar yaitu: Gedung sekolah, Ruang Belajar, Sarana dan Prasarana Eskul.Dimensi responsiveness yang meliputi indikator-indikator yang mempengaruhi kualitas pelayanan pendidikan Sekolah Dasar yaitu: Respon kepala sekolah, Respon guru, Respon staf sekolah. Dimensi assurance yang meliputi indikator-indikator yang mempengaruhi kualitas pelayanan pendidikan Sekolah Dasar yaitu: Pengetahuan dan kemampuan kepala sekolah, Pengetahuan dan kemampuan guru, Pengetahuan dan kemampuan staf sekolah.Dimensi emphaty yang meliputi indikator-indikator yang mempengaruhi kualitas pelayanan pendidikan Sekolah Dasar yaitu: Perhatian kepala sekolah, Perhatian guru, Perhatian staf sekolah. Dimensi reliability yang meliputi indikator-indikator yang mempengaruhi kualitas pelayanan pendidikan Sekolah Dasar yaitu: Keandalan kinerja kepala sekolah, Keandalan kinerja guru, Keandalan kinerja staf sekolah.

\section{KESIMPULAN}

Berdasarkan hasil penelitian dan pembahasan dapat diambil kesimpulan sebagai berikut:

1. Tahapan implementasi kebijakan Sekolah Dasar Standar Nasional yang telah dilaksanakan di Kabupaten Wajo sejak tahun ajaran 2008/2009 belum dilaksanakan secara optimal dikarenakan terjadi overlapping pekerjaan antara implementasi kebijakan Sekolah Dasar Standar Nasional, dengan kebijakan lain yang harus dilaksanakan oleh Dinas Pendidikan Kabupaten Wajo. 
2. Faktor-faktor determinan yang mempengaruhi implementasi kebijakan Sekolah Dasar Standar Nasional diantaranya dukungan sumberdaya dalam implementasi kebijakan Sekolah Dasar Standar Nasional masih sangat terbatas, salah-satunya staf/pegawai yang tidak cukup memadai, mencukupi, ataupun tidak kompeten dalam bidangnya.

3. Wujud implementasi kebijakan Standar Nasional Pendidikan pada penyelenggaraan Sekolah Dasar Standar Nasional di Kabupaten Wajo adalah kurang termotivasinya sekolah dasar untuk ikut terlibat dalam pelaksanaan kebijakan SD-SN, terutama sekolah dasar kategori standar.

Dari hasil penelitian diberikan rekomendasi sebagai berikut :

1. Pembinaan Sekolah Dasar Standar Nasional pada jenjang sekolah dasar sangat membutuhkan adanya sistem pengelolaan komprehensif, mulai dari perencanaan, pengorganisasian, pelaksanaan, pengkoordinasian, dan pemantauan serta evaluasi hingga mencapai suatu sistem pembinaan Sekolah Dasar Standar Nasional yang benar-benar sesuai dengan ketentuan.

2. Mutu pendidikan yang masih rendah, diharapkan Sekolah Dasar Standar Nasional pada jenjang Pendidikan Sekolah Dasar dimulai dengan mengacu kepada kondisi lapangan.

3. Diperlukan kerjasama yang baik dengan semua pihak atau stakeholders dalam penyelenggaraan program Sekolah Dasar Standar Nasional melalui upaya memperoleh kesamaan pandangan dan tanggungjawab terhadap pembinaan Sekolah Dasar Standar Nasional pada jenjang Sekolah Dasar baik dari tingkat pemerintah pusat, daerah maupun sekolah dan stakeholders terkait, sehingga benar-benar mampu membentuk sekolah-sekolah mandiri yang sesuai dengan harapan.

\section{DAFTAR PUSTAKA}

Ary, H. Gunawan, (1996), Administrasi Sekolah: Administrasi Pendidikan Mikro (Jakarta: PT. Rineka Cipta.

Anderson, James E, 1984, Public Policy Making, Second Edition, Houghton Miffilin Company, USA.

Arikunto, S., dan Lia Y., 2008.Manajemen Pendidikan. Yogyakarta: Kerjasama UNYAditya Media, Edisi ke-1.

Bungni, Burhan, 2011. Penelitian Kualitatif: Komunikasi, Ekonomi, Kebijakan Publik, dan IImu Sosial, Cetakan Kelima, Jakarta : Putra Grafika.

Dunn, N. W. 2000. Pengantar Analisis Kebijakan Publik. Alih bahasa: Samodra Wibawa dkk. Yogyakarta: Gadjah Mada University Press.

Dwiyanto, Agus, 2005, Mewujudkan Good Governance Melalui Pelayanan Publik, Jakarta: Gadjah Mada University Press

Edward III, George C, 1980. Implementing Public Policy. Washington: Congressional Quarterly, Inc.

Grindle, Merilee S, (ed.) 1980. Politics and Policy Implementation in the Third World, New Jersey: Princetown University Press.

Idrus, Ali. 2009. Manajemen Pendidikan Global (Visi, Aksi dan Adaptasi). Jakarta. Gaung Persada (GP Press).

Irianto Yoyon Bahtiar, 2011. Kebijakan Pembaruan Pendidikan, Konsep, Teori dan Model. Rajawali Press. Jakarta.

Mulyana, Dedi, 2007, IImu Komunikasi, Bandung: PT Remadja Rosdakarya

Mulyasa, E, 2007, Kurikulum Tingkat Satuan Pendidikan, Bandung: PT Remadja Rosdakarya

Mulyasa, E, 2004, Implementasi Kurikulum 2004-Panduan Pembelajaran KBK, Bandung: PT Remadja Rosdakarya 
Keban, Y.T. 2008. Enam Dimensi Strategi Administrasi Publik(Konsep, Teori dan Isue). Yogyakarta: Penerbit Gaya Media.

Mater, Van and Van Horn, 1975. The Policy Implementation Process: A Conceptual Frame Work. Amsterdam Van Meter and Van Horn Administration \& Society.

Mazmanian, Daniel H, dan Paul A. Sabatier, 1983. Implementation and Public Policy, New York :Haperc Collins.

Miles, M.B dan Huberman, M. 1992. Analisis Data Kualitatif Terjemahan oleh Tjetjep Rohendi Rohidi, Jakarta, UI Press.

Mulyasa E. 2003: Manajemen Berbasis Sekolah: PT Rosdaka. Bandung.

Mulyasa E. 2007.Kurikulum Tingkat Satuan Pendidikan, Bandung: Remadja Rosdakarya.

Peraturan Pemerintah Nomor 19 Tahun 2005 Tentang Standar Nasional Pendidikan.

Peraturan Pemerintah Nomor 17 Tahun 2010 Tentang Pengelolaan dan Penyelenggaraan Pendidikan.

Tilaar, 2006.Standarnisasi Pendidikan Nasional, Suatu Tinjauan Kritis. Rineka Cipta. Jakarta.

Tjiptono, Fandy dan Diana, Anastasia. 1996. Total Quality Management, Yogyakarta : Andi Ofset.

Zeithaml, Valarie, A. Parasuraman and Leonard L. Berry, 1990, Devering Quality Service, New York: The Free Press. 